\title{
Protection Effects of Allylmercaptan, Metabolite of Garlic on Endothelial Cell Injury Induced by Oxidized Low Density Lipoprotein
}

\section{Seung Taek Yang*}

Department of Food Science and Biotechnology, Kyungsung Universtiy, Busan 608-736, Korea

Received September 27, 2010 /Accepted November 252010

\begin{abstract}
Oxidation of low density lipoprotein (LDL) has been recognized as an important role in the initiation and progression of atherosclerosis. In this study, effects of allylmercaptan, a major metabolite compound of garlic, was studied on endothelial cell injury induced by oxidized low density lipoprotein (ox-LDL). The antioxidative activity of allylmercaptan was investigated by monitoring a thiobarbituric acid substance (TBARS). Allylmercaptan inhibited LDL oxidation induced by $\mathrm{Cu}^{2+}$ at concentrations of $0.1,1$ and $10 \mathrm{mM}$ in a dose dependent manner. Lactate dehydrogenase (LDH) release, as an index of cell injury, and intracellular glutathione levels were determined. Pulmonary artery endothelial cells were preincubated with allylmercaptan at $37^{\circ} \mathrm{C}$ and $5 \% \mathrm{CO}_{2}$ for $24 \mathrm{hr}$, washed, and then exposed to $0.1 \mathrm{mg} / \mathrm{ml}$ oxidized LDL for $24 \mathrm{hr}$. Preincubation of endothelial cells with allylmercaptan significantly prevented the LDH release and depletion of GSH. Peroxides were measured directly in 24 well plates using a fluorometric assay. Allylmercaptan inhibited release of peroxides induced by ox-LDL in pulmonary artery endothelial cells. In a free system, allylmercaptan was shown to scavenge hydrogen peroxide. The data indicate that allylmercaptan can protect pulmonary artery endothelial cells from injury caused by oxidized LDL, and suggest that allylmercaptan may be useful for the prevention of atherosclerosis.
\end{abstract}

Key words : Allylmercaptan, oxidized low density lipoprotein (ox-LDL), atherosclerosis

\section{Introduction}

Oxidation of low-density lipoprotein (LDL) is recognized as playing an important role in the initiation and progression of atherosclerosis [2,26]. It is well established that LDL is the major cholesterol carrier in the blood, and the elevation of LDL in plasma level is correlated with increased risk of atherosclerosis and cardiovascular disease [3,4]. LDL does not cause atherosclerosis plaques in its native form, but the oxidative modification of LDL may contribute to the pathology of atherosclerosis leading to plaque build up arteries and consequently coronary heart disease [5]. LDL can be oxidized by incubation of endothelial cell, smooth muscle cells [14], or macrophages monocytes [13] with a transition metal such as copper [15] of oxidized LDL (ox-LDL) induced cell injury $[16,27]$.

Evidence in support of the oxidized LDL hypothesis also comes from studies using antioxidants. Ox-LDL is crucial to atherogenesis the potential role of antioxidants in the prevention of the oxidative modification of LDL assumes great

\footnotetext{
${ }^{*}$ Corresponding author

Tel : +82-51-663-4715, Fax : +82-51-622-4986

E-mail : scyang@ks.ac.kr
}

importance. Therefore, the inhibitory of LDL oxidation has been suggested as a novel approach to impede atherogenesis.

S-allylmercaptan is one of the major metabolite compounds in garlic and aged garlic extract $[6,9,22]$. Recent studies indicated that allylmercaptan reduces cholesterol synthesis in rat hepatocytes, although its inhibitory effect appears to be much less than that of allicin [29]. Another possible indication bioavailability of sulfur containing compounds, it seemed possible to have antioxidative effects on LDL oxidation. Synthetic antioxidants, such as the drug probucol, have been prescribed as an adjunct therapy along with other vasodilators [17]. However, their toxicity limits their usage and ultimately, their potential as therapeutic agent. On the other hand, many naturally occuring antioxidant derived from plant products offer similar protection, without the associated toxicity.

In this study, the antioxidant effects of allylmercaptan were determined using several in vitro assay system. This experiment now report that allylmercaptan can minimize release of lactate dehydrogenase, depletion of intracellular glutathione (GSH) and the release of peroxides induced by ox-LDL. 


\section{Materials and Methods}

\section{Chemicals}

Allylmercaptan $85 \%$ pure, plus $12 \%$ diallyl sulfide and $1 \%$ diallyl disulfide by HPLC analysis was provided by Nature's way products Inc. (Springville, UT, USA.). Cupric sulfate $\left(\mathrm{CuSO}_{4} \cdot \mathrm{H}_{2} \mathrm{O}\right)$ was obtained from Baker Chemical Co. (Phillsburg, NJ. USA). Hank's balanced salt solution (HBSS), Triton X-100, trichloroacetic acid (TCA), hydrogen peroxide $\left(\mathrm{H}_{2} \mathrm{O}_{2}\right)$, ethylenediamine tetraacetic acid (EDTA), 5'5'-dithio- bis(2-nitrobenzoic acid), and phosphate buffered saline (PBS) were purchased from Sigma Chemical Company (St. Louis, MO). Horseradish peroxidase and 2,2'-azino-di-[3-ethylbenzthiazoline-6-sulfonic acid] (ABTS) were obtained from Boehringer Mannheim Company (Indianapolis, IN, USA). 2',7'-dichlorofluorescin diacetate was purchase from Molecular Probes (Eugene, OR, USA). Cytotox $96^{\mathrm{TM}}$ Nonradioactive Cytotoxicity Assay Kit was supplied by, Promega Co. (Madison, WI, USA). Eagles minimum essential medium (EMEM), penicillin-streptomycin solution and Trypsin-EDTA solution were obtained from Mediatech Co. (Washington, DC, USA). Bovine calf serum (BCS) and fetal calf serum (FCS) were obtained from Hyclone Laboratory (Logun, UT. USA).

\section{Cell culture}

Pulmonary artery endothelial cells (PAECs) was obtained from American Type Culture Cellection (Rockville, MD, USA). PAECs were grown in EMEM with 20\% BCS and 200 $\mu / \mathrm{ml}$ penicillin-streptomycin solution. All cells were incubated at $37^{\circ} \mathrm{C}$ in a $5 \%$ humidified $\mathrm{CO}_{2}$ atmosphere for at least 3 4 days before use. Throughout the experiments, cell viability was always greater than $95 \%$ as determined by trypan blue exclusion.

\section{Preparation of $0 x-L D L$}

Ox-LDL was prepared by the method of Heinecke [12]. Protein content was determined using the method of Lowry et al. [13], while the presence of ox-LDL was confirmed via agarose gel electrophoresis [10].

\section{TBARS measurement}

Various concentration of allylmercaptan in $0.1 \mathrm{ml}$ volumes and $0.1 \mathrm{ml}$ of LDL $(0.2 \mathrm{mg}$ protein $/ \mathrm{ml})$ were added to $0.5 \mathrm{ml}$ of $0.5 \mu \mathrm{M} \mathrm{CuSO}_{4}$ and incubated at $37^{\circ} \mathrm{C}$ for 60 $\mathrm{min}$. The reaction was stopped by adding $0.1 \mathrm{ml}$ of $10 \mathrm{mM}$
EDTA. The extent of peroxidation was determined by measuring thiobarbituric acid reactive substance (TBARS) [7].

\section{Lactate dehydrogenase release}

The PACEs $\left(8 \times 10^{4}\right.$ cells/well $)$ in 24 -well plates were preincubated with $0.1,1$, and $10 \mathrm{mM}$ of allylmercaptan for 24 $\mathrm{hr}$, washed with HBBS, and then incubated with $0.1 \mathrm{mg} / \mathrm{ml}$ Ox-LDL in HBBS for $24 \mathrm{hr}$. The supernatant was collected from each well and stored at $4^{\circ} \mathrm{C}$. Cell monolayers were treated with $0.2 \mathrm{ml}$ of $0.8 \%$ Triton $\mathrm{X}-100$ for $30 \mathrm{~min}$ at room temperature to disrupt cell membranes. The lysates were then collected. Lactate dehydrogenase (LDH) activity was measured in both the supernatant and the cell lysate fractions using the Cyto-Tox96 Nonradioactive Cytotoxicity Assay Kit following the manufacturer's instruction. This assay is based on the conversion of a tetrazolium salt into red formazan product. The intensity of color is proportional to LDH activity. Absorbance was determined at $492 \mathrm{~nm}$ with a 96-well plate enzyme-linked immunosorbent assay (ELISA) reader (400 AT ETA, Whittaker Bioproducts, Walkersville, MD, USA). Percentage LDH released from the cells was determined using the formula

Percent release $=\mathrm{LDH}$ activity in supernatant / $(\mathrm{LDH}$ activity in supernatant $+\mathrm{LDH}$ activity in cell lysate)

\section{Determination of intracellular glutathione (GSH)}

Intracellular GSH was determined according to the method of Sedlak and Lindsay [25]. The PACEs $\left(4.0 \times 10^{6}\right.$ cells) in $75 \mathrm{~cm}^{2}$ flask were preincubated with different concentrations of allylmercaptan for $24 \mathrm{hr}$, washed with HBSS, and then incubated with $0.1 \mathrm{mg} / \mathrm{ml}$ ox-LDL in HBSS for $24 \mathrm{hr}$. After cell monolayers were washed with Ham's HBSS to remove ox-LDL, they were treated with $0.2 \mathrm{ml}$ of $0.8 \%$-Triton X-100 for $20 \mathrm{~min}$ at room temperature to lyse cell membranes. To measure the intracellular GSH, $0.2 \mathrm{ml}$ of the lysates were added to $0.2 \mathrm{ml}$ of $10 \%$-TCA, and the mixture was centrifuged at $15,000 \mathrm{rpm}$ for $10 \mathrm{~min}$ at $4^{\circ} \mathrm{C}$. To the supernatant was added $0.5 \mathrm{ml}$ of $0.4 \mathrm{M}$ Tris- $\mathrm{HCl}$ buffer $(\mathrm{pH} \mathrm{8.9)}$ and $20 \mathrm{ml}$ of $10 \mathrm{mM}$ DTNB-methanol solution. The absorbance was then measured at $412 \mathrm{~nm}$. The GSH level was compared with that of endothelial cells without exposure to ox-LDL and expressed as percentage of control.

\section{Determination of peroxides}

Released peroxides were measured by flurometric assay using $2^{\prime}, 7^{\prime}$-dichlorofluorescin diacetate (DCFH-DA) as a 
probe [28]. Upon exposure to peroxides, non-fluorescent DCFH-DA becomes deacetylated and is transformed into $2^{\prime}, 7^{\prime}$-dichloroflurescein (DCF), which exhibit a characteristic absorbance and emissions at $485 \mathrm{~nm}$ and $550 \mathrm{~nm}$. PACEs were grown to confluency on 24-well plates. Allylmercaptan at concentrations of $0.1,1,10$ and $20 \mathrm{mM}$ was added to the medium $24 \mathrm{hr}$ before ox-LDL stimulation. Cells were washed twice with HBSS, and $10 \mathrm{ml}$ of $0.5 \mathrm{mM}$ DCFH-DA were added to each well prior to stimulation, Time course studies were then performed using ox-LDL. Fluorescein intensity was measured every $20 \mathrm{~min}$ for $3 \mathrm{hr}$ using a 7620 microplate fluorometer (Cambridge Tee. Watertown. MH. USA).

\section{$\mathrm{H}_{2} \mathrm{O}_{2}$ scavenging assay}

The scavenging effect of allylmercaptan on $\mathrm{H}_{2} \mathrm{O}_{2}$ was determined according to the method of Okamoto, Hayase et al. [24] One-tenth $\mathrm{ml}$ of $50 \mathrm{nM} \mathrm{H} \mathrm{O}_{2}, 0.1 \mathrm{ml}$ of different concentrations of allylmercaptan of HBSS, $0.6 \mathrm{ml}$ of $10 \mathrm{U} / \mathrm{ml}$ peroxidase, and $0.6 \mathrm{ml}$ of $0.1 \%$ ABTS were added to $1.8 \mathrm{ml}$ of $0.1 \mathrm{M}$ phosphate buffer ( $\mathrm{pH}$ 6.0). The solution was then incubated at $37^{\circ} \mathrm{C}$ for $15 \mathrm{~min}$. Absorbance at $414 \mathrm{~nm}$ was measured using the spectrophotometer.

\section{Statistical analysis}

Data were analyzed using a one-way analysis of variance (ANOVA) followed by Turky's multiple range test for significant difference, and results were expressed as the mean \pm SE. A $p$ value of less than 0.05 was considered significant. All statistical procedures were performed with statgraphics software version 5.0 (STSC. Inc. Rockville, MD. USA).

\section{Results and Discussion}

Inhibitory effects of allylmercaptan on Ox-LDL

LDL oxidation in vitro previously upon incubation with metal ions or with activated endothelial cells gas been demonstrated (Parthasarathy et al. 1985,). Moreover, our laboratory gas demonstrated that ox-LDL induces membrane damage in bovine enSdothelial cells as measured by lactate dehydrogenase release [16].

Antioxidative effects of sulfur containing compounds, allylmercaptan on the oxidation of $\mathrm{LDL}$, as measured by production of TBARS. $\mathrm{Cu}^{2+}$ ions was found to be effective at initiating the oxidation of LDL as measured by TBARS. To obtain the ox-LDL, LDL was oxidized by $\mathrm{Cu}^{2+}$ in the time de- pendent manner and the production of TBARS reached a plateau after $60 \mathrm{~min}$ of incubation. Each experiment was repeated at least three times. With consistent results indicating that the assays used in this study were highly reproducible LDL incubation with $\mathrm{CuSO}_{4}$ resulted in a significant increase TBARS. Upon coincubation with varying concentration of allylmercaptan, its effect on TBARS formation was most noticeable at 1 and $10 \mathrm{mM}$ (Fig. 1A). The known antioxidant butylated hydroxytoluene (BHT) was used as a positive control (Fig. 1B).

Addition of allylmercaptan resulted in dose-dependent decrease in LDL oxidation, as measured by reduced TBARS formation. Likewise, the effect of the known antioxidant, $\mathrm{BHT}$, on $\mathrm{Cu}^{2+}$-induced TBARS formation was examined and compared to the effect of allylmercaptan. These results indicate allylmercaptan has substancial antioxidant properties and may inhibit LDL oxidation via antioxidant mechanisms. Studies involving chemical analysis of garlic suggest that organosulfur compounds are responsible for the bioactive [23]. Particles are innocuous, possessing lipophilic antioxidants $(a$ -toccopherol and $\beta$-carotene) to protect against oxidant attack $[25,31]$.

Allylmercaptan possess a reducing sulfur center attached to organic side groups, enabling stabilization of their negative charge. This combination in chemical structure thus confers strong antioxidant properties upon some of those compounds [1]. Allylmercaptan is recognized as a significant allyl sulfur compound occuring in garlic preparations [29]. Among these, our laboratory has placed emphasis on

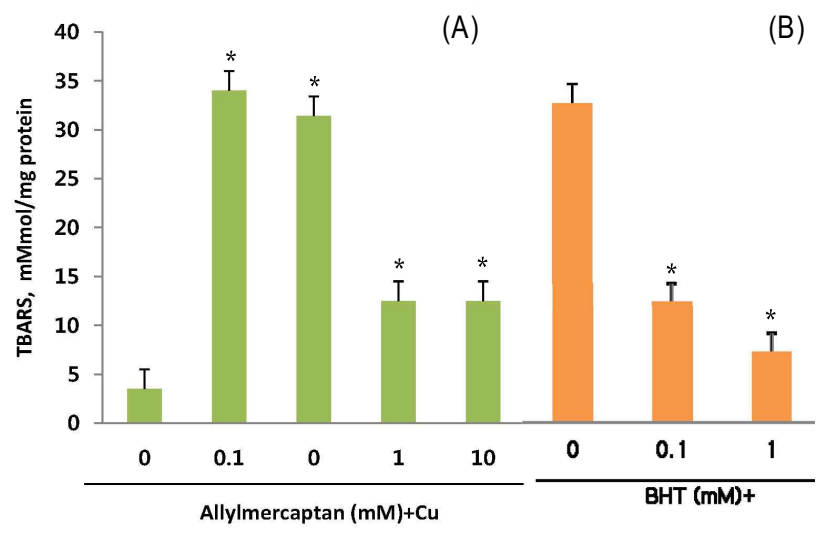

Fig. 1. The effect of allylmercaptan on $\mathrm{Cu}^{2+}$-induced LDL oxidation (A) and BHT (B) as control. Data represents mean \pm SE of triplicate samples. "Significant differences $(p<0.05)$ compared with samples exposed to ox-LDL but without pretreatment with allylmercaptan. 
allylmercaptan. Antioxidants have been the focus of recent studies involving the atherosclerotic process, primarily because of the oxidant-dependent nature of atherogenic initiation.

\section{Effects of LDH release and GSH level}

Low-density lipoprotein oxidation has been recognized as playing an important role in the intiation and progression of atherosclerosis [5,28]. LDL has been shown to be oxidized by cultured cells such as macrophages and enothelial and smooth muscle cells with transition metals. Ox-LDL appears ti ubitiate vascular dysfunction by directly promoting cytitixicity. Effects of allylmercaptan on LDH release (histogram) and GSH level (line graph) when cells were exposed to $0.1 \mathrm{mg} / \mathrm{ml}$ ox-LDL (Fig. 2). Ox-LDL caused an increase in LDH release and a decrease in intracellular GSH compared with cells not exposed to ox-LDL. Pretreatment of cells with allylmercaptan resulted in a dose-dependent inhibition of LDH release and intracellular GSH depletion. Ox-LDL appears to initiate vascular function by directly promoting cell cytotoxicity. It can alter the composition and permeability of the endothelial barrier and it thus cytotoxic for endothelial cell [11]. Previously some reports indicated that garlic compounds inhibit $\mathrm{Cu}^{2+}$ induced LDL oxidation [15] and protect vascular endothelial cells from ox-LDL induced cell injury [16].

In the present study, LDL release was measured as an index of cell injury. LDH is an intracellular enzyme that leaks from cells when their membranes are damaged. Ox-LDL caused an increase in LDH release, indicating cell injury. This detail indicated that preincubation with allylmercaptan significantly inhibited the increase in LDH release induced by ox-LDL, showing the protective effects of

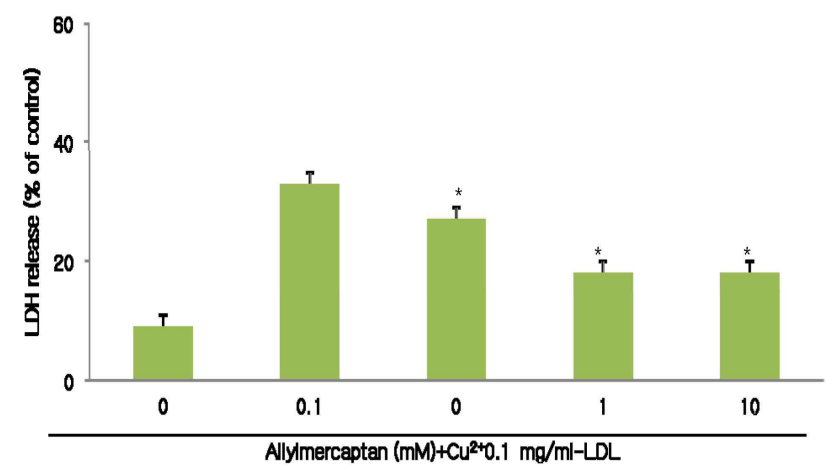

Fig. 2. Effects of allylmercaptan on $\mathrm{LDH}$ release and intracellular GSH. Histogram depicts LDH release.

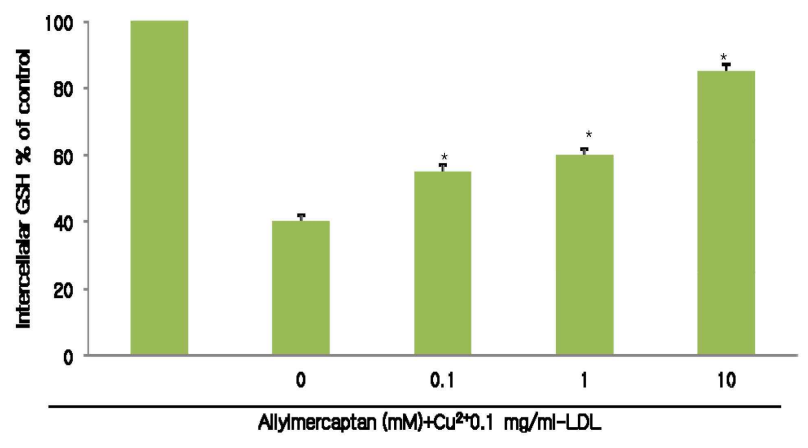

Fig. 3. Effect of allylmercaptan on intracellular GSH. Data represent means $\pm S E$ of triplicate samples. Untreated indicates that cell were not exposed to ox-LDL. "Significant difference $(p<0.05)$ compared with samples exposed to ox-LDL but without pretreatment with allylmercaptan.

its compound on the cell membranes. Allylmercaptan exhibited a dose dependent inhibition of ox-LDL induced LDL release.

The effect of allylmercaptan on GSH level when cells were exposed to $0.1 \mathrm{mg} / \mathrm{ml}$ ox-LDL. Ox-LDL caused a decrease in intracellular GSH compared with cells not exposed to ox-LDL. Pretreatnebt if cekks with allylmercaptan resulted in dose independent of intracellular GSH delpletion (Fig. 3)

Ox-LDL has been shown to deplets intracellar GSH in cultured endothelial cells. Intracellular GSH depletion can lead to increased endothelial cell susceptibility to injury caused by ox-LDL [19]. GSH is the most abundant low molecular weight thiol compound in the cell and plays an important role in antioxidant defense and detoxification. GSH depletion compromises cell defences against oxidative damage and may lead to cell death [20]. Although the mechanism of allylmercaptan is not clearly understood, it has been suggested that allylmercaptan could interfere with cellular sulfur hydryl $(\mathrm{SH})$ homeostasis by affecting the glutathione (GSH) by the sulfoxide group. It has been shown that allylmercaptan inactivates GSH depletion by reacting with the $\mathrm{SH}$ group of the enzyme and formation of the mixed disulfide. The depletion of GSH results in protein-SH oxidation, peroxidation and disturbances of cellular metabolism, which may lead to cell death.

This data indicate that incubation of PAECs with ox-LDL for $24 \mathrm{hr}$ caused a decrease of total GSH. Preincubation of PAECs with allylmercaptan prevented GSH depletion, suggesting that its compound can be a potent protective agent against ox-LDL induced cytotoxicity. 


\section{Effects of allylmercaptan on peroxide}

Under oxidant-stressed conditions, peroxides such as $\mathrm{H}_{2} \mathrm{O}_{2}$ and lipid peroxides change cell function and interaction with surrounding cells. For unstance, $\mathrm{H}_{2} \mathrm{O}_{2}$ serves as an important second messenger in the activation of the transcriotion factor, $\mathrm{NF}_{-\mathrm{k}} \mathrm{B}$, which is associated with expression of cell adhesion factors, vascular cell adhesion molecule-1 (VCAM-1), and intercellular adhesion molecule-1 (ICAM=1) [8,27]. Furthermore, $\mathrm{H}_{2} \mathrm{O}_{2}$ damages cell membranes, reduces cell viability, and induces lipid peroxidation [32]. $\mathrm{H}_{2} \mathrm{O}_{2}$ also yields hydrixyl radicals $(\mathrm{OH})$ by reacting with a transition metal such as $\mathrm{Fe}^{2+}$ or $\mathrm{Cu}^{2+}$. Generation of these hydroxyl radicals results in DNA damage and lipid peroxidation, leading to cell dysfunction and death. Lipid peroxides in endothelial cells change the permeability of cell membranes and ion efflux.

Peroxide release was measured using a fluorometric using a fluorometer assay. ox-LDL concentrations at $0.1 \mathrm{mg} / \mathrm{ml}$ were used to stimulate the PACEs (Fig. 3) and DCF formation was measured. Incubation of PACEs with ox-LDL caused an increase of fluorescence, indicating release of peroxides. Allylmercaptan inhibited this release in a dose-dependent manner.

Moreover, exposure of PACEs to oxidized LDL resulted in a significant release of peroxides. Allylmercaptan demonstrated a similar dose-dependent decrease in DCF formation abeit to a much lesser extent (Fig. 4A). Even after $24 \mathrm{hr}$ of coincubation, allylmercaptan still exerted its inhibition at concentrations of 10 and $20 \mathrm{mM}$ (Fig. 4B). The results establish significant allylmercaptan inhibition of peroxide permetion in PACEs cell line.

The results was induced upon stimulation of PACEs cell lines. Once LDL oxidative modification has occurred, the ox-LDL particle can exert a myriad of pathogenic effects in atherosclerotic progression. With its native LDL receptor domain cleaved during oxidative modification, ox-LDL moves across the cell membrane via an alternate scavenge receptor abundant on the cell surfaces of endothelial cells [20]. Such event may accelerate the formation of atherogenic lesions and cell death.

In a times course study, allylmercaptan inhibited release of peroxide in endothelial cells dose-dependently while still retaining its inhibitory effect $24 \mathrm{hr}$ later. It also observed the direct scavenging effect of allylmercaptan on peroxides. Although several beneficial antioxidative properties of allylmercaptan have been reported [8], this study presents a novel

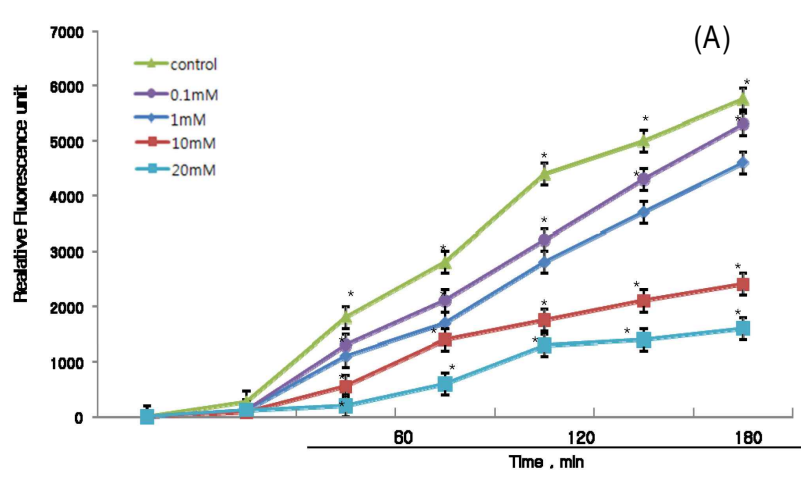

(B)

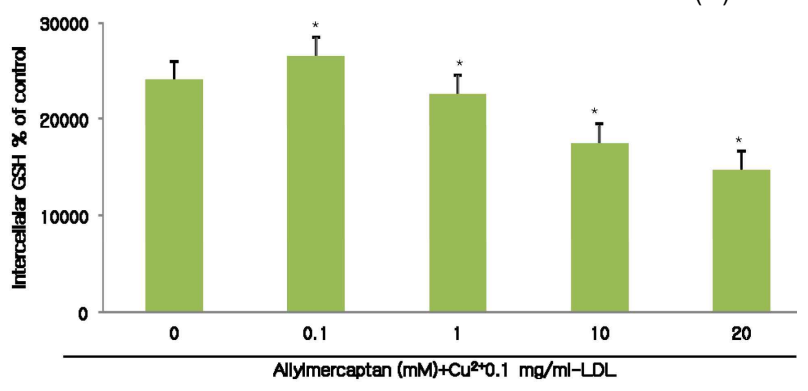

Fig. 4. Effects of allylmercaptan on release of peroxides. PACES were incubated with $0.1 \mathrm{mg} / \mathrm{ml}$ ox-LDL and various concentrations of allylmercaptan. 2' $7^{\prime}$-Dichlorofluorerescein fluorescence, indicating release of peroxides was monitored every $30 \mathrm{~min}$ for $3 \mathrm{hr}$ (Fig. 3A). Release of peroxides was also measured at $24 \mathrm{hr}$ (Fig. 3B). Data represent mean \pm SE of triplicate samples. "Significant difference $(p<0.05)$ compared with control exposed to ox-LDL without allylmercaptan.

activity, suggesting that allylmercaptan may reduce the peroxides and may thus be useful for pathologies associated with oxygen species.

\section{Scavenging effects of hydrogen peroxide}

Table 1 shows the scavenging effect of directly allylmercaptan on hydrogen peroxide. Decreases of hydrogen peroxide reflecting scavenging by allylmercaptan were noted,

Table 1. Scavenging effect of allylmercaptan on hydrogen peroxide

\begin{tabular}{ccc}
\hline Allylmercaptan $(\mathrm{mM})$ & $\mathrm{H}_{2} \mathrm{O}_{2}(\mathrm{nmol} \pm \mathrm{SE})$ & Scavenging $(\%)$ \\
\hline 0 & 5.00 & - \\
0.1 & $4.90 \pm 0.08^{*}$ & 2.0 \\
1 & $4.03 \pm 0.08^{*}$ & 19.4 \\
10 & $0.98 \pm 0.06^{*}$ & 80.4 \\
20 & $1.02 \pm 0.06^{*}$ & 79.6 \\
\hline
\end{tabular}

Data represent mean \pm SE of triplicate samples.

"Significant difference compared with samples without allylmercaptan $(p<0.05)$. 
with significant activity observed at the concentration of 0.1 , 1,10 and $20 \mathrm{mM}$ of allylmercaptan.

Under the oxidative stress conditions, peroxides such as hydrogen peroxides and lipid peroxides change cell function and interaction with surrounding endothelial cell. For instance, hydrogen peroxide serves as an important second messenger in the activation of the transcription factor, NF-kB which is associated with expression of cell adhesion factors, vascular cell adhesion molecule, and intracellular adhesion molecule[26]. Furthermore, $\mathrm{H}_{2} \mathrm{O}_{2}$ damages cell membranes, reduces cell viability, and induce lipid peroxidation [30]. $\mathrm{H}_{2} \mathrm{O}_{2}$ yields hydroxyl radical $(\bullet \mathrm{OH})$ by reacting with a transition metal such as $\mathrm{Cu}^{2+}$ and $\mathrm{Fe}^{2+}$. Generation of these hydroxyl radicals results in DNA damage and lipid peroxidation, leading to cell dysfunction and death.

This results observed the direct scavenging effect of allylmercaptan on hydrogen peroxide. This data thus suggest that allylmercaptan can protect endothelial cells from oxidant injury by removing the intracellular peroxides such as hydrogen peroxide and lipid peroxide.

The dependence of the atherogenic process on oxidation and peroxide generation makes antioxidant intervention a feasible therapentic measure. In recent years, probucol has been employed as a therapeutic adjunct with other antiarteriosclerosis drugs with great success [30]. Although originally intended as a cholesterol-lowering agent, its antioxidant properties were soon recognized and put on clinical use. Synthetic antioxidants, such as the drug probucol [18], have been prescribed as an adjunct therapy along with other vasodilators [30]. The lipophilic properties of probucol allow it to incorporate evenly in cellular membranes in a fashion similar to many of the tocopherol antioxidants. However, as with many lipophilic compounds, a limit to beneficial effects is reached as increased concentration membrane chemistry. Therefore, hydrophilic antioxidants such as SAC become increasingly significant oxidant scavengers, as limits to the intake of lipophilic antioxidants are attained. The hyrophilic nature of SAC allows it to not only react with oxidant molecules imbedded in cellular membranes (i.e., lipid perooxides), but also to scavenge the extracellular medium for more hydrophilic ROs such as superoxdied anions and hydroxyl radicals. Therefore, SAC exerts a synergistic effect in reducing oxidant load by scavenging extracellular and membrane-bound oxidants, while concomitantly regenerating lipid-soluble antioxidants. However, their toxicity limits their usage and ultimately, their potential as therapeutic agents. On the other hand, many naturally occuring antioxidants [17] derived from natural products such as allylmercaptan offer similar protection.

In conclusion, the data from this in vitro study indicate that allylmercaptan may protect endothelial cells from ox-LDL induced injury by preventing depletion of GSH and removing peroxides, and suggest that allylmercaptan may be useful in the prevention of atheriosclerosis.

\section{Acknowledgement}

This research was supported by Kyungsung University Research Grants in 2010.

\section{References}

1. Block, E. 1992. The organosulfur chemistry of the genus Allium implications for the organic chemistry of sulfur. Angew Chem Int. Ed Engl. 31, 1135-1178.

2. Bonetti, P. O., L. O. Lerman, and A. Lerman. 2003. Endothelial dysfunction. A marker of atherosclerotic risk. Artherioscler. Thromb. Uasc. Biol. 23, 188-175.

3. Cai, H. and D. G. Harrison. 2001. Endlothelial dysfunction in cardiovascular diseases: the role of oxidant stress. Crit. Res. 87, 840-844.

4. Cathcart, M. K., D. W. Morel, and G. M. Chisolm. 1985. Monocytes and neutrophiles oxidized low density lipoprotein making it cytotoxic. J. Leukocyte Biol. 38, 341-350.

5. Cox, D. A. and M. L. Cohen. 1996. Effects of oxidized low density lipoprotein on vascular contraction and relaxation: clinical and pharmacological implications in atherosclerosis. Pharmacol. Rev. 48, 3-19.

6. Egon-Schmind, C., R. Eckardm, and E. H. Kemper. 1992. Metabolism of garlic constituents in the isolated perfused rat liver. Planta Med 58, 301-305.

7. Esterbauer, H., G. Strigel, H. Puhl, and M. Rotheneder. 1989. Continuous monitoring of in vitro oxidation of human low density lipoprotein. Free Radic. Res. Commun. 6, 67-75.

8. Geng, Z., Y. Rong, and B. H. S. Lau. 1997. S-Allylcysteine inhibits activation of nuclear factor kappa B in human $\mathrm{T}$ cells. Free Radic. Biol. Med 23, 345-350

9. Gebhardt, R. and H. Beck. 1996. Differential inhibitory effects of garlic-derived organosulfur compounds on cholesterol biosynthesis in primary rat hepatocyte cultures. Lipids 31, 1269-1276.

10. Greenspan, P. and R. L. Gutman. 1993. Detection by nile red of agarose fell electrophoresed native and modified low density lipoprotein. Electrophoresis 14, 65-68.

11. Guretzk, H. J., K. D. Gerbitz, B. Olgemoller, and E. Schleicher. 1994. Atherogenic levels of low density lipoprotein alter the permeability and composition of the endothelial barrier. Aherosclerosis 107, 15-24. 
12. Heinecke, J. W. 1987. Free radical modification of low-density lipoprotein: Mechanisms and biological consequences. Free Rad Biol. Med 3, 65-73.

13. Henriksen, T., E. M. Mahoney, and D. Steinberg. 1981. Enhanced macrophage degradation of biologically modified low density lipoprotein. Atherosclerosis 3, 149-159.

14. Henriksen, T., E. M. Mahoney, and D. Steinberg. 1981. Enhanced macrophage degradation of low density lipoprotein previously incubated with cultured endothelial cells: Recognition by receptors for acetylated low density lipoprotein. Proc. Natl. Acad Sci. USA 78, 6449-6504.

15. Ide, N., A. B. Nelson, and B. H. S. Lau. 1997. Aged garlic extract and its constituents inhibit $\mathrm{Cu}^{2+}$-induced oxidative modification of low density lipoprotein. Planta Med 63, 263-264.

16. Ide, N. and B. H. S. Lau. 1997. Garlic compounds protect vascular endothelial cells from oxidized low density lipoprotein-induced injury. J. Pharm Pharmacol. 49, 908-911.

17. Parthasarathy, S., U. P. Steinbrecher, J. Barnett, J. L. Witzum, and D. Steinberg. 1985. Essential role of phospholipase $\mathrm{A}_{2}$ activity in endothelial cell-induced modification of low-density lipoprotein. Proc. Natl. Acad Sci. USA 82, 3000-3004.

18. Kuzuya, M. and F. Kuzuya. 1993. Probucol as an antioxidant and antiatherogenic drug. Free Radic. Biol. Med 14, 67-77.

19. Kuzuya, M., M. Naito, C. Funaki, T. Hayashi, K. Asai, and F. Kuzuya. 1989. Protective role of intracellular glutathione against oxidized low density lipoprotein in cultured endothelial cells. Biochem Biophys. Res. Commun. 163, 1466-1472.

20. Kuzuya, M., M. Naito, C. Funaki, T. Hayashi, K. Asai, and F. Kuzuya. 1991. Lipid peroxide and transition metals are reqired for the toxicity of oxidized low density lipoprotein to cultured endothelial cells. Biochim Biophys. Acta. 1096, 155-161.

21. Lowry, O. H., N. J. Rosebrough, A. L. Farr, and R. J. Randall. 1951. Protein measurement with the Folin phenol reagent. J. Biol. Chem 193, 265-275.

22. Lawson, L. D. 1993. Bioactive organosulfur compounds of garlic and garlic products: Their role in reducing blood lipids. In human medicinal agents from plants. In Kinghorn, A. D. and M. F. Balandrin (eds.), pp. 306-330, American Chemical Society. Washington, DC, USA.

23. Lawson, L. D. 1996. The composition and chemistry of garlic cloves and processed garlic, in garlic: The science and therapeutic application of allium sativum L. and related species. 2nd eds. In Koch, H. P. and L. D. Lawson (eds.), pp. 37-107, Williams and Wilkins, Baltimore.

24. Okamoto, G., F. Hayase, and H. Kato. 1992. Scavenging of active oxygen species by glycated protein. Biosci. Biotech Biochem 56, 928-931.

25. Ryu, B. H., J. W. Jeung, L. G. Robert, and P. Greenspan. 1990. Antioxidative activity for human low density lipoprotein oxidation by a novel compound purified from marine microbial origin. J. Marine Biotech 81, 175-182.

26. Sedlak, J. and R. H. Lindsay. 1968. Estimation of total, protein-bound, and nonprotein sulfhydryl groups in tissue with Ellman's reagent. Anal. Biochem 25, 192-205.

27. Sen, C. K. and L. Packer. 1996. Antioxidant and redox regulation of gene transcription. FASEB 10, 709-720.

28. Steinberg, D., S. Parthasarathy, T. E. Carew, J. C. Khoo, and J. L. Witztum. 1989. Beyond cholesterol: Modification of low-density lipoprotein that increase its atherogenicity. $N$. Engl. J. Med 320, 915-924.

29. Wan, C. P., E. Myung, and B. H. S. Lau. 1993. An automated micro-fluorometric assay for monitoring oxidative burst activity of phagocytes. J. Immunol. 159, 131-138.

30. Xu, S. and B. H. Simon Cho. 1999. Allyl mercaptan, a major metabolite of garlic compounds, reduces cellular cholesterol synthesis and its secretion in Hep-G2 cells. J. Nutr. Biochem 10, 654-659.

31. Yang, S. T. 2007. Antioxidative activity of extracts of aged black garlic on oxidation of human low density lipoprotein J. Life Sci. 17. 1330-1335.

32. Yamasaki, T., L. Li, and B. H. S. Lau. 1994. Garlic compounds protect vascular endothelial cells from hydrogen peroxide-induced oxidant injury. Phytother. Res. 8, 408-412. 
초록 : 산화된 low density lipoprotein (LDL)에 의해 유도된 내피세포의 손상에 대한 마늘 대사산물 인 allylmercaptan의 보호 효과

양 승 택*

(경성대학교 식품생명공학과)

Low density lipoprotein (LDL)의 산화는 동맥경화의 유발과 진행에 결정적 역할을 하는 것으로 알려져 있다. 본 연구에서는 마늘의 주요 대사산물인 allylmercaptan의 산화 low density lipoprotein에 의해 손상된 내피세포 의 보호효과에 대하여 실험하였다. Allylmercaptan의 항산화 활성은 thiobarbituric acid substance (TBARS)로 측 정하였다. Allylmercaptan은 $0.1,1$ 및 $10 \mathrm{mM}$ 의 농도에서 $\mathrm{Cu}^{2+}$ 에 의해 유도된 $\mathrm{LDL}$ 의 산화를 용량의존적으로 억 제하였다. 폐동맥 내피세포를 $37^{\circ} \mathrm{C}, 5 \% \mathrm{CO}_{2}$ 상태에서 24 시간 동안 미리 배양시킨 후 세측한 다음 다시 24 시간 동안 $0.1 \mathrm{mg} / \mathrm{ml}$ oxidized LDL (ox-LDL)을 첨가하여 배양하였다. 이 때 ox-LDL이 Lactate dehydrogenase (LDH) 의 방출과 glutathione (GSH)를 감소시키는 원인으로 세포막 손상의 지표로 LDH와 GSH 함량을 조사하였다. 본 실험 결과 allylmercaptan을 일정 농도 별로 endothelial cell에 첨가하여 배양했을 때 $\mathrm{LDH}$ 의 방출과 GSH의 감 소를 현저하게 억제하였다. Peroxide를 형광분석법으로 24 well plate에서 직접 측정한 결과 allylmercaptan이 폐 동맥 내피세포 내에서 ox-LDL 유도 peroxide의 방출을 억제하였다. 그리고 allylmercaptan은 과산화수소의 소거 능도 있었다. 본 실험결과 allylmercaptan은 ox-LDL 유도 폐동맥 내피세포를 보호할 수 있었으므로 allylmercap$\tan$ 은 동맥경화의 예방에 유용할 것으로 생각된다. 